\title{
Phytoplankton growth rates in the Ross Sea, Antarctica
}

\author{
Anna F. Mosby*, Walker O. Smith Jr. \\ Virginia Institute of Marine Science, College of William and Mary, Gloucester Point, Virginia 23062, USA
}

\begin{abstract}
The Ross Sea is a highly productive region of the Southern Ocean, but phytoplankton growth rates there are poorly constrained. Variability in growth rates was investigated on a January-February 2012 cruise to the Ross Sea using $37{ }^{14} \mathrm{C}$ isotopic tracer incubations and 11 dilution experiments. We examined the effects of extended incubations on measured growth rates in ${ }^{14} \mathrm{C}$ incubations, quantified phytoplankton growth and grazing mortality rates through dilution experiments, and analyzed the effects of irradiance on carbon:chlorophyll ratios in dilution experiments. Growth rates in ${ }^{14} \mathrm{C}$ incubations ranged from 0.03 to $0.85 \mathrm{~d}^{-1}$. We found that chlorophyllbased phytoplankton growth rates in dilution experiments differed from measurements based on cell abundance, and concluded that chlorophyll-based growth rates may be inaccurate due to changing carbon:chlorophyll ratios during incubations. Unbalanced phytoplankton growth among experiments was likely due to acclimation due to different mixed layer depth at stations sampled and incubation at constant irradiance. Growth rates measured in $72 \mathrm{~h}{ }^{14} \mathrm{C}$ incubations were not markedly different from those conducted over $24 \mathrm{~h}$, indicating that loss of fixed ${ }^{14} \mathrm{C}$ through grazing and respiration was not a significant source of error. All growth rates measured were significantly below those predicted based on temperature. As rates of grazing are low and physical conditions vary spatially, ${ }^{14} \mathrm{C}$ incubations may be a more appropriate means of measuring growth rates than dilution experiments in the Ross Sea.
\end{abstract}

KEY WORDS: Growth rate $\cdot$ Ross Sea $\cdot$ Phytoplankton $\cdot$ Dilution method $\cdot{ }^{14} \mathrm{C} \cdot$ Temperature

\section{INTRODUCTION}

The Ross Sea is among the most productive regions in the Southern Ocean, characterized by a short growing season during which phytoplankton distribution and biomass are highly variable in space and time (Arrigo et al. 2008b, Smith \& Comiso 2008). In addition to the importance of phytoplankton as the base of a diverse food web, high primary production in the Ross Sea serves as a significant carbon sink for the entire Southern Ocean (Arrigo et al. 2008a). The Southern Ocean is considered to be a diatom-dominated system, but the haptophyte Phaeocystis antarctica serves as an additional important bloom-forming species in the Ross Sea and other regions (El-Sayed et al. 1983, Davidson \& Marchant 1987, Smith \& Gor- don 1997). The presence of this species has important implications for food webs, as P. antarctica forms large colonies that may deter grazing by some zooplankton, which in turn could restrict trophic transfer of carbon (Caron et al. 2000, Smith et al. 2003).

Phytoplankton growth in Antarctic waters is typically limited by 3 main factors: temperature, irradiance, and micronutrient supply. Based on the relationship between temperature and maximum growth rate established by Eppley (1972), maximum growth rates in the Ross Sea should be ca. 0.53 to $0.67 \mathrm{~d}^{-1}$, although other treatments give different estimates. For example Bissinger et al. (2008) predict an intrinsic growth rate $(\mu)$ of $0.81 \mathrm{~d}^{-1}$ at $0^{\circ} \mathrm{C}$. However, the importance of temperature in regulating plankton growth rates has been questioned (Sherr \& Sherr 
2009). Phytoplankton growth can also be light-limited, as the Ross Sea is covered by sea ice for much of the year, and water columns in early spring are characterized by relatively deep mixed layers (Smith et al. 2000, 2014). As sea ice breaks up and stratification increases due to meltwater input, iron limitation plays an increasingly important role in controlling phytoplankton growth (Sedwick et al. 2000, 2011). It is likely that the factors limiting growth in austral summer vary spatially, resulting in variable phytoplankton growth rates throughout the Ross Sea.

Only a few studies have directly measured growth rates of phytoplankton in the Ross Sea (Smith et al. 1999, Caron et al. 2000), despite the fact that growth rate is a fundamental property of microbial growth that is linked to critical oceanic processes (Laws 2013) and is an essential input to coupled biogeochemical models (e.g. Sarmiento et al. 1998). Measurements of phytoplankton growth rates in the ocean are frequently collected, but have substantial uncertainties; rarely are the methodological concerns associated with these estimated rates addressed. Methods for their measurement include assessing changes in biomass through time (e.g. Eppley 1972), quantifying isotopic incorporation coupled with biomass estimates (Eppley 1968), assessing the time-dependent changes of cellular pools such as ATP (Sheldon \& Sutcliffe 1978), measuring the incorporation of isotopes into protein (DiTullio \& Laws 1983), and using dilution techniques (Landry \& Hassett 1982). These methods, however, require the use of bottle incubations and are therefore susceptible to errors from 'bottle effects', in which rates measured are a reflection of an artificial environment rather than in situ rates. The bottle effect can result in changed phytoplankton and grazer assemblages and depletion of nutrients (Venrick et al. 1977, Agis et al. 2007). The different manifestations of the bottle effect are likely to become more pronounced as incubation length is increased; however, samples must be incubated long enough to ensure that measured growth rates will not be influenced by diel cycles, and to ensure that changes in the measured variables are large enough to be detected (Landry 2014). Typical incubation lengths for measuring growth rates are ca. $24 \mathrm{~h}$ (e.g. Landry \& Hassett 1982, Smith et al. 1998), but Caron et al. (2000) determined that $24 \mathrm{~h}$ incubations did not yield significant results for phytoplankton mortality in dilution experiments, and suggested that incubations needed to be as long as $72 \mathrm{~h}$ in polar waters. Low temperatures and high macronutrient concentrations in polar regions mean that extended incubations are unlikely to alter measured phytoplankton growth rates through bottle effects, but the effect of longer incubations on phytoplankton growth rates has not been examined.

There are additional errors associated with different methods that are unique to the methods concerned and typically violate its underlying assumptions. This means that certain methodologies for measuring growth rates may be more appropriate in certain regions. The primary concern with measuring growth rate using ${ }^{14} \mathrm{C}$ incubations is the possible loss of the incorporated isotope via grazing and respiration (Eppley 1980, Laws et al. 1987). Grazing rates and respiratory losses in the Ross Sea are considered to be low (Tagliabue \& Arrigo 2003), in part due to low temperatures (Rose \& Caron 2007), suggesting that underestimates of growth rates using ${ }^{14} \mathrm{C}$ incubations would be small, but the impact of bottle effects on isotope incorporation remains uncertain.

The dilution technique (e.g. Landry \& Hassett 1982, Caron et al. 2000) measures phytoplankton mortality as well as phytoplankton growth rates by examining changes in chlorophyll concentrations over time. However, in the Ross Sea, dilution experiments can have 2 major sources of uncertainty: the presence of colonial P. antarctica, and photoacclimation during incubation and consequent unbalanced growth among experiments (Landry et al. 2002, Schmoker et al. 2013). Previous studies in Phaeocystis-rich systems have yielded extremely low phytoplankton growth and mortality rates; it is suggested that the presence of Phaeocystis may contribute to inaccurate measurements because the formation of colonies may be a mechanism to avoid grazing (Caron et al. 2000, Calbet et al. 2011). Additionally, for changes in chlorophyll to provide an accurate measure of phytoplankton growth rates, the amount of chlorophyll per cell of the phytoplankton must remain constant through time (Gallegos \& Vant 1996). In regions such as the Ross Sea that are heterogeneous in terms of mixed layer depth, photoacclimation and subsequent unbalanced growth during extended incubations might lead to inaccurate growth rates based on chlorophyll.

Previous studies in the Ross Sea have focused on isotopic incorporation coupled with biomass estimates to determine phytoplankton growth rates (Smith et al. 1999). These studies indicated that growth rates are typically below the temperature-defined maximum, but estimates vary based on the isotope used and the phytoplankton functional group being assessed (Smith et al. 1999). Smith et al. (2000) found a strong unimodal peak in growth rates that was correlated with biomass, with mean growth rates in spring aver- 


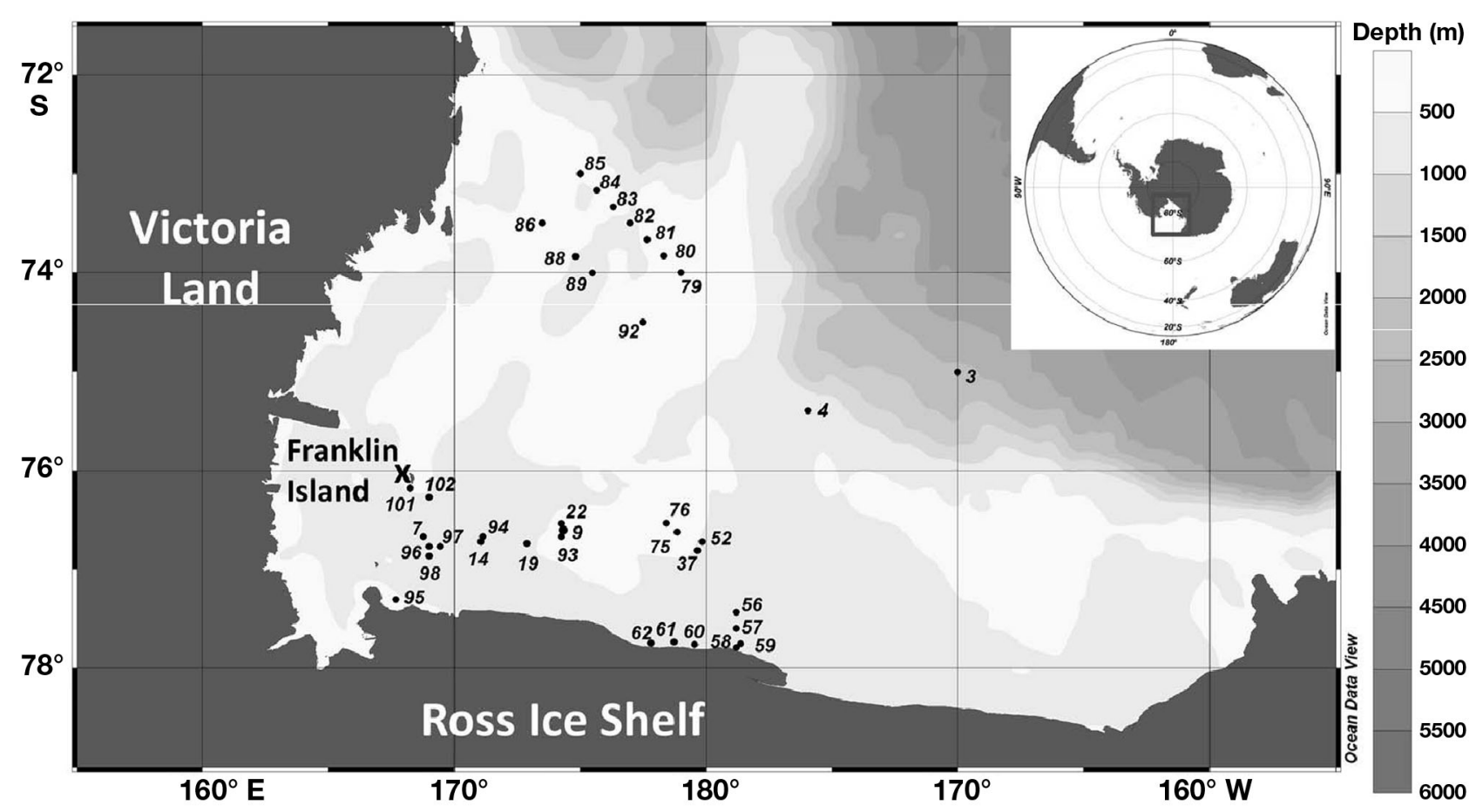

Fig. 1. Location of sampling stations for investigation of phytoplankton growth rates in the Ross Sea in January-February 2012. Contours indicate water depth (m)

aging $0.27 \mathrm{~d}^{-1}$. As sea ice broke up and stratification of the water column increased, growth rates increased, but decreased in the summer, when they averaged $0.059 \mathrm{~d}^{-1}$, which may have indicated iron limitation.

We measured phytoplankton growth rates in the Ross Sea in austral summer using ${ }^{14} \mathrm{C}$ uptake and dilution experiments. Our first objective was to examine the effect of incubation length on measured growth rate in ${ }^{14} \mathrm{C}$ incubations (Eppley 1968) and dilution experiments (Landry \& Hassett 1982). We hypothesized that incubations could be extended to $72 \mathrm{~h}$ without significant changes in growth rates. Our second objective was to compare phytoplankton growth rates measured using ${ }^{14} \mathrm{C}$ incubations to those measured within dilution experiments to test the hypothesis that growth rates in dilution experiments would not significantly differ from those determined by ${ }^{14} \mathrm{C}$ incubations. Dilution experiments were analyzed to determine whether the presence of $P$. antarctica led to low phytoplankton grazing mortality rates and to examine possible shifts in carbon:chlorophyll ratios over the duration of incubation. The final objective was to test the hypothesis that growth rates are significantly less than the temperature-defined maximum growth rate (Eppley 1972), and to use ancillary environmental data to explore potential limiting factors of phytoplankton growth in the Ross Sea.

\section{MATERIALS AND METHODS}

\section{Study site and sampling procedure}

Sampling for growth rate determinations was conducted in the Ross Sea from 8 January to 2 February 2012 from the Research Vessel/Icebreaker (RVIB) 'Nathaniel B. Palmer' (cruise NBP12-01) as a part of the project PRISM-RS (Processes Regulating Iron Supply at the Mesoscale - Ross Sea). ${ }^{14} \mathrm{C}$ incubations were carried out at 37 stations (Fig. 1); dilution experiments were also done at 11 of the 37 stations (Fig. 1). Water samples were collected from $10 \mathrm{~m}$ using a Sea Bird 911+ CTD system containing twenty-four 101 Niskin bottles. Water samples were collected for chlorophyll $a$ and particulate organic carbon (POC) analyses at all stations. For dilution experiments, water was gently filtered through $200 \mu \mathrm{m}$ mesh screen to remove any mesozooplankton. Further processing took place in a cold room at $0^{\circ} \mathrm{C}$.

\section{Analytical methods}

Temperature at $10 \mathrm{~m}$ depth was determined from the CTD profiles, and mixed layer depths were estimated from density profiles of the CTD up-casts and based on changes in potential density $\left(\sigma_{t}\right)$ of $0.01 \mathrm{~kg}$ 
$\mathrm{m}^{-3}$ from the $\sigma_{\mathrm{t}}$ value at $10 \mathrm{~m}$ (Thomson \& Fine 2003). Chlorophyll a concentrations were determined via fluorometry (JGOFS 1996). The fluorometer was calibrated using commercially prepared chlorophyll a (Sigma). Errors for replicate chlorophyll determinations are ca. 5\% (Smith et al. 2013). For particulate organic carbon (POC) measurements, 0.25 to $1.0 \mathrm{l}$ of water was filtered under low vacuum through combusted $\left(450^{\circ} \mathrm{C}\right.$ for $\left.2 \mathrm{~h}\right)$ Whatman GF/F filters. Filters were rinsed with ca. $5 \mathrm{ml}$ of $0.01 \mathrm{~N} \mathrm{HCl}$ in filtered seawater, placed in combusted glass vials capped with combusted aluminum foil, and dried at $60^{\circ} \mathrm{C}$. POC samples were analyzed in the laboratory via pyrolysis on a Costech ECS 4010 elemental analyzer. Blanks were filters through which filtered seawater had been run (ca. $5 \mathrm{ml}$ ) and treated in the same manner (Gardner et al. 2000). POC errors for replicate samples are ca. 10\% (Smith et al. 2013).

Whole seawater samples were preserved in $10 \%$ acid Lugol's solution and analyzed in the laboratory for phytoplankton composition (Mosby 2013). Subsamples ranging from 10 to $50 \mathrm{ml}$ volume (based on chlorophyll concentrations) were settled in an Utermöhl counting chamber for a minimum of $24 \mathrm{~h}$ and

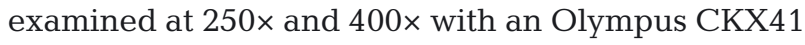
inverted microscope. Microzooplankton were categorized by functional group and size. Acid Lugol's preservation does not allow for designation of dinoflagellates into autotrophic, mixotrophic, or heterotrophic categories. Although many dinoflagellates are heterotrophic or mixotrophic (Flynn et al. 2013), we treated them as phytoplankton for calculations of abundance-based growth rates, which potentially could lead to an underestimate. However, dinoflagellates did not contribute significantly to biomass, and our results did not change when they were excluded. As a result, the inclusion of dinoflagellates as phytoplankton does not have a significant impact on our conclusions.

Phytoplankton were identified to genus or species level. The entire contents of the Utermöhl chamber were counted except for solitary Phaeocystis antarctica and the diatom Cylindrotheca closterium, which were the most numerically abundant species in all samples. Colonial $P$. antarctica was enumerated using the Utermöhl chamber, and abundance was analyzed by counting all cells in colonies. Solitary $P$. antarctica and C. closterium were enumerated using a Sedgwick-Rafter counting chamber. Samples were mixed, transferred to the counting chamber, and settled for a minimum of 15 min before examination. Three transects of thirty grids were analyzed for species abundance. Counting precision was esti- mated for all species and samples to a 95\% confidence limit (Hötzel \& Croome 1999). Rare species were not used for determination of growth rates based on abundance.

The sizes of the 10 most common species were estimated to determine average cell volume and carbon content. For each, at least 50 cells were measured to determine average length and width and the standard deviation and coefficient of variation were determined for each. Average cell volume was then determined from the average dimensions and formulas for their closest geometric shape. Volumes were then converted to carbon based on the volume $\left(\mu \mathrm{m}^{3}\right)$ to carbon (pg C) models of Eppley et al. (1970), Smayda (1978), Menden-Deuer \& Lessard (2000), and Beers \& Stewart (1970).

\section{${ }^{14} \mathrm{C}$ incubations}

Sample water was distributed into triplicate $345 \mathrm{ml}$ Qorpak tissue culture flasks and inoculated with 20 to $40 \mu \mathrm{Ci}{ }^{14} \mathrm{C}$ bicarbonate, capped, and gently inverted several times. Qorpaks were then placed in an incubator cooled with running seawater and screened to $36 \%$ of surface irradiance to simulate irradiance at $\sim 10 \mathrm{~m}$. After $24 \mathrm{~h}$, an entire bottle was removed and processed. Total added radioactivity was determined from a $100 \mu \mathrm{l}$ subsample placed in a $7 \mathrm{ml}$ scintillation vial with $100 \mu \mathrm{l} \beta$-phenethylamine (a $\mathrm{CO}_{2}$ trap) and $5 \mathrm{ml}$ Ecolume ${ }^{\circledR}$ fluor. The remaining sample was divided into 100 and $245 \mathrm{ml}$ portions and filtered through $25 \mathrm{~mm}$ GF/F filters. Filters were rinsed with ca. $5 \mathrm{ml} 0.01 \mathrm{~N} \mathrm{HCl}$ in filtered seawater and placed in scintillation vials with $5 \mathrm{ml}$ Ecolume ${ }^{\circledR}$. After $24 \mathrm{~h}$, samples were analyzed for isotope incorporation using a liquid scintillation counter (Beckman) and counted to a $1 \%$ counting error. The remaining Qorpaks were processed similarly after 48 and $72 \mathrm{~h}$.

Carbon assimilation was determined for each time point, and growth rates $(\mu)$ were estimated from time-series ${ }^{14} \mathrm{C}$ uptake measurements (Eppley 1968) and initial POC concentrations (Smith et al. 1999):

$$
\mu=\frac{1}{t} \ln \left(\frac{P_{0}+\Delta P}{P_{0}}\right)
$$

where $P_{0}$ is the initial particulate organic carbon concentration $\left(\mu \mathrm{g} \mathrm{l}^{-1}\right), \Delta P$ the change in organic carbon $\left(\mu \mathrm{g} \mathrm{l}^{-1}\right.$ ) over the course of the incubation as determined from radioisotope incorporation, and $t$ the incubation length (d). 


\section{Dilution experiments}

All experiments were conducted using a 2-point modification of the dilution technique (Ducklow \& Hill 1985, Strom et al. 2006, Landry et al. 2008). Water was first filtered through a $0.2 \mu \mathrm{m}$ Whatman cartridge filter to generate filtered seawater, and untreated (but filtered through a $200 \mu \mathrm{m}$ net) seawater was gently added to achieve a final concentration of $20 \%$ whole seawater (wsw). A $20 \%$ dilution was chosen a priori based on the dilutions of Caron et al. (2000), who used a $20 \%$ dilution as the lowest dilution tested. Three $1.2 \mathrm{l}$ bottles were sampled from both the $20 \%$ and $100 \%$ wsw treatments. Nutrients were not added to the bottles as the Ross Sea is typically characterized by high concentrations of macronutrients (Sedwick et al. 2000). Micronutrients (iron) were not added as sampling and sample handling were not trace-metal free. The bottles were placed in the incubator and processed after $72 \mathrm{~h}$ (Caron et al. 2000). At the end of the incubation, triplicate $250 \mathrm{ml}$ samples were analyzed for chlorophyll from each bottle; a $250 \mathrm{ml}$ sample was preserved in acid Lugol's (final concentration of $10 \%$ ) for microscopic analysis from each wsw treatment.

Chlorophyll and particulate organic carbon was used as a proxy for biomass to determine apparent growth rate $(k)$ using an exponential growth equation (Landry \& Hassett 1982):

$$
k=\left(\frac{1}{t}\right) \ln \left(\frac{N_{t}}{N_{0}}\right)
$$

where $N_{t}$ is the chlorophyll (POC) concentration at time $t$, and $N_{0}$ is the chlorophyll (POC) concentration prior to incubation. For all statistical tests, $\alpha$ was a priori set equal to 0.05 . Apparent growth rates were obtained for all samples, and a 2-tailed $t$-test was used to determine whether growth rates in the $100 \%$ wsw treatment were significantly different from those in the $20 \%$ wsw treatment. If apparent growth rates did not differ significantly among treatments, grazing mortality was defined as 0 . If apparent growth rates were significantly lower in the $20 \%$ wsw sample, signifying a negative grazing rate (which is theoretically impossible, but has been observed previously in dilution experiments), all statistical tests were conducted with these grazing rates included but set to zero (Menden-Deuer \& Fredrickson 2010). For stations with a significant difference in apparent growth rates between treatments, grazing mortality $(m)$ was calculated as:

$$
m=\frac{k_{\mathrm{d}}-k}{1-D}
$$

where $k_{\mathrm{d}}$ is apparent growth rate in the $20 \%$ wsw treatment, $k$ is apparent growth rate in wsw treatment, and $D$ is the fraction of undiluted seawater (Landry \& Hassett 1982, Li et al. 2011). The intrinsic growth rate $(\mu)$ was calculated for those stations with significant positive grazing rates as:

$$
\mu=\frac{k_{\mathrm{d}}-k D}{1-D}
$$

according to Li et al. (2011). Apparent growth rates were used as intrinsic growth rates at stations that did not show significantly different growth rates between treatments. Carbon biomass based on microscopic analysis was summed for each sample, and apparent growth rates based on total carbon concentrations calculated for all stations using Eq. (2).

\section{Statistical analyses}

To determine the factors influencing measured ${ }^{14} \mathrm{C}$ growth rates, data were transformed using a natural log transformation to fit the assumptions of normality and homogeneity of variance using the Box-Cox transformation (Neter et al. 1996). Growth rates from $24 \mathrm{~h}$ incubations were compared to the temperaturedefined maximum growth rates (Eppley 1972) using a 1-tailed $t$-test to determine significant deviations from this theorized rate. Measured growth rates at $24 \mathrm{~h}$ were regressed against initial biomass - both in terms of POC and chlorophyll concentrations, which were log-transformed using the Box-Cox transformation - to evaluate the relationship between standing stock and growth rate (least-squares regression). The effect of incubation length was analyzed using analysis of covariance (ANCOVA) as a function of initial biomass based on POC $\left(\mu \mathrm{g} \mathrm{Cl}^{-1}\right)$.

To determine the factors influencing growth and grazing rates from dilution experiments (such as photoacclimation), apparent growth rates based on fluorometric analysis and cell abundance were tested for normality (Shapiro-Wilks) and analyzed without transformation. Net abundance- and chlorophyllbased growth rates from $72 \mathrm{~h}$ dilution experiments were compared to temperature-defined maximum growth rate using a 1-tailed $t$-test. Measured growth rates were tested for correlations (Pearson correlation) with environmental variables (temperature, nutrient concentrations, and mixed layer depth) and initial biomass (chlorophyll and POC concentrations). Relative biomass of each functional group (diatoms, prymnesiophytes, dinoflagellates, and silicoflagellates) and relative abundance of microzooplankton 
were compared between initial and final time points to determine whether there was a shift in assemblage composition over the course of the incubation (2-tailed $t$-test).

To determine whether there were changes in the carbon:chlorophyll ratios during dilution experiments, ratios were calculated using total carbon concentrations derived from microscopy and average chlorophyll concentrations at the corresponding time point. Percentage changes in carbon:chlorophyll ratios were then calculated based on the difference in calculated ratios in initial and final samples. Measured changes were tested for correlation with temperature and mixed layer depth as well as initial biomass (Pearson and Spearman correlations). Pearson correlations were used if datasets were normally distributed (Shapiro-Wilks); otherwise, Spearman correlations were used. Abundance-based growth rates were compared to chlorophyll-based growth rates using a Pearson correlation. Because samples were taken from the same bottle, least squares regression should yield a significant positive regression; increases in chlorophyll-based growth rates should correlate with increasing abundance-based growth rates under balanced growth. Growth rates were compared between ${ }^{14} \mathrm{C}$ incubations and dilution experiments to determine whether the 2 methods were significantly different. Because growth rates were not expected to be normally distributed, growth rates across treatments were compared using a Friedman test, blocking by initial biomass $\left(\mu \mathrm{g} \mathrm{chl} \mathrm{a} \mathrm{l}^{-1}\right)$.

Table 1. Ranges and means (with standard deviations) of (a) environmental parameters at stations sampled for investigation of phytoplankton growth rates in the Ross Sea, and (b) phytoplankton growth rates $\left(\mathrm{d}^{-1}\right)$ measured in 24,48 , and $72 \mathrm{~h}{ }^{14} \mathrm{C}$ incubations. MLD: mixed layer depth; Fe: iron concentration at $10 \mathrm{~m}_{\text {; }}$ POC: particulate organic carbon at $10 \mathrm{~m}$; C:Chl: carbon:chlorophyll ratio

\begin{tabular}{|c|c|c|}
\hline Variable & Range & Mean (SD) \\
\hline \multicolumn{3}{|c|}{ (a) Environmental parameters } \\
\hline Temperature $\left({ }^{\circ} \mathrm{C}\right)$ & -1.31 to +2.11 & $-0.17(0.69)$ \\
\hline $\operatorname{MLD}(\mathrm{m})$ & $10-97$ & $20(18.8)$ \\
\hline $\mathrm{Fe}(\mathrm{nM})$ & $0.03-0.42$ & $0.07(0.09)$ \\
\hline $\operatorname{POC}\left(\mu g \mathrm{l}^{-1}\right)$ & $11.3-659$ & $241(197)$ \\
\hline Chl a $\left(\mu \mathrm{g} \mathrm{l}^{-1}\right)$ & $0.22-10.5$ & $3.9(3.1)$ \\
\hline $\mathrm{C}: \mathrm{Chl}(\mathrm{w}: \mathrm{w})$ & $10.4-393$ & $81.7(90.6)$ \\
\hline \multicolumn{3}{|c|}{ (b) Growth rates $\left(d^{-1}\right)$ in ${ }^{14} C$ incubations } \\
\hline $24 \mathrm{~h}$ incubation & $0.03-0.85$ & $0.11(0.14)$ \\
\hline $48 \mathrm{~h}$ incubation & $0.04-0.59$ & $0.10(0.10)$ \\
\hline $72 \mathrm{~h}$ incubation & $0.03-0.49$ & $0.12(0.09)$ \\
\hline
\end{tabular}

\section{RESULTS}

\section{Phytoplankton biomass and composition}

Chlorophyll and POC concentrations ranged from

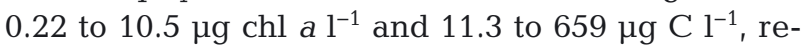
spectively, indicating high variability in abundance of phytoplankton across stations sampled (Table 1a). Temperature and mixed layer depths also varied substantially, ranging from -1.31 to $2.11^{\circ} \mathrm{C}$ and 10 to $97 \mathrm{~m}$, respectively; high temperatures were correlated with shallower mixed layers (Spearman correlation, $\rho=$ $-0.76, p=0.006)$. Dissolved iron concentrations ranged from 0.03 to $0.42 \mathrm{nM}$ (Table 1a), but were not correlated with other environmental variables.

Species present included several species of diatoms, the prymnesiophyte Phaeocystis antarctica in colonial (unflagellated, encased in an envelope) and solitary (flagellated) form, and the silicoflagellate Dictyocha speculum. Calculated cellular biomass was comparable to phytoplankton biomass estimates previously observed (Mathot et al. 2000). Diatomaceous carbon was greatest relative to total phytoplankton biomass at all but one station, with an aver-

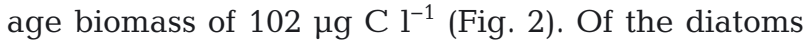
observed, the pennate diatom Cylindrotheca closterium was most abundant, ranging from 14 to 7900

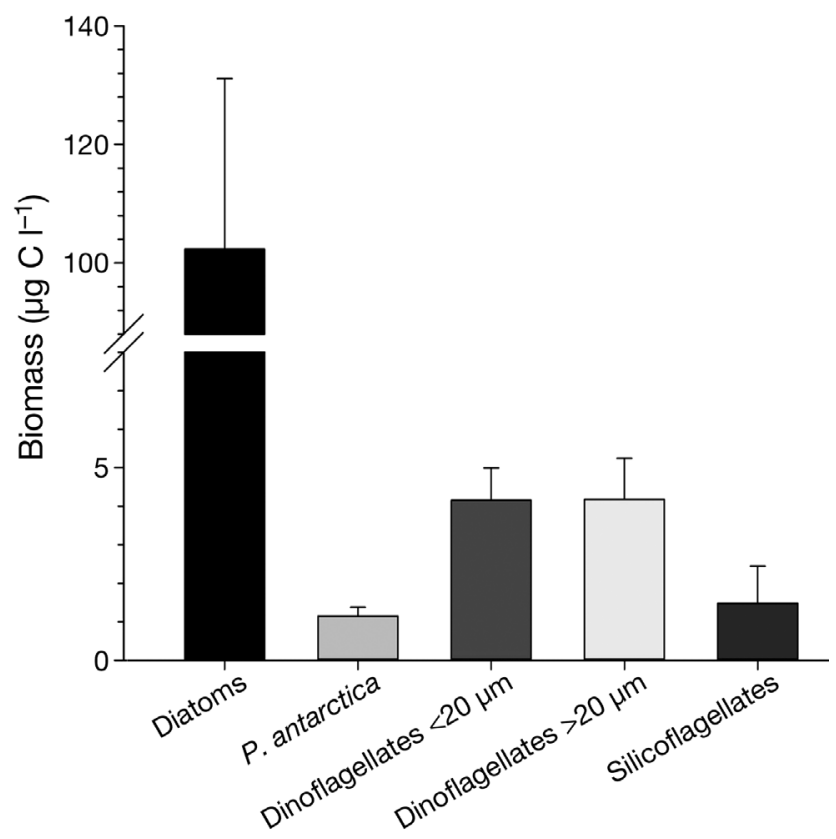

Fig. 2. Mean initial biomass ( $\mu \mathrm{g} \mathrm{C}^{-1}$ ) of Ross Sea phytoplankton in dilution experiments $(n=11)$ derived from cell length and width measurements and conversion into carbon units using volume-to-carbon conversions from the literature. Error bars are standard errors 


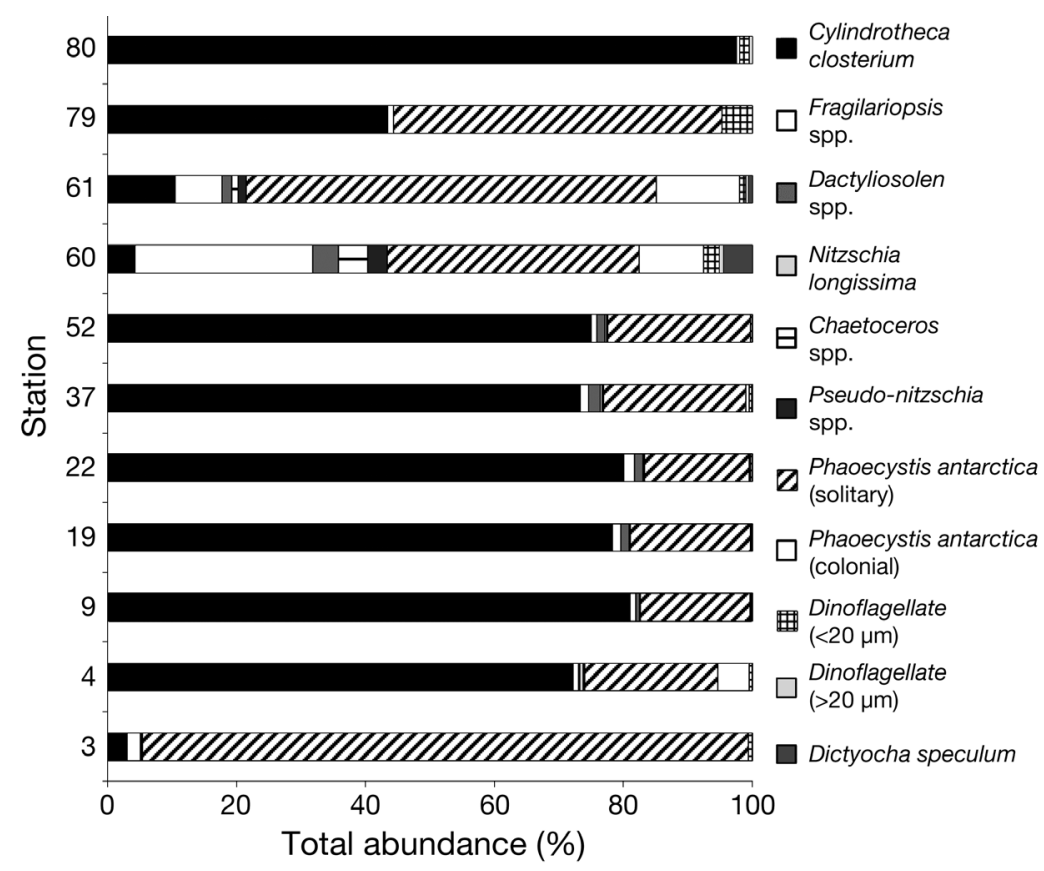

Fig. 3. Initial phytoplankton composition in dilution experiments $(\mathrm{n}=11)$, shown as percentage of total abundance $\left(\right.$ cells $\mathrm{ml}^{-1}$ ) based on average abundance in all cell counts. Phaeocystis antarctica was classified as solitary or colonial. Dinoflagellates were classified as small $(<20 \mu \mathrm{m})$ or large $(>20 \mu \mathrm{m})$

contributing a maximum of $76 \%$ of the cell numbers (Fig. 3), but contributed the lowest average biomass $\left(1.1 \mu \mathrm{g} \mathrm{C}^{-1}\right)$ across the sampling region (Fig. 2) due to the low cellular carbon content (Table 2). The solitary forms were consistently more abundant than colonies, but colonies were present at most stations (Fig. 3).

Small dinoflagellates $(<20 \mu \mathrm{m})$ were on average more abundant than larger dinoflagellates (>20 $\mu \mathrm{m})$ (Fig. 4). Dinoflagellate abundance was high at Stn 3 and one Ross Ice Shelf station (Stn 61), and at Stns 79 and 80 (Fig. 3). Dictyocha speculum (a prasinophyte) abundance was also highest at the 2 Ross Ice Shelf stations (Stns 60 and 61), but was present only at one additional station (Stn 37) (Fig. 3). Aloricate ciliates ranged from 2000 to 19000 cells $1^{-1}$ (Fig. 4), and average abundance was 12300 cells ${ }^{-1}$, but abundance was not correlated with phytoplankton biomass. Of all functional groups, small dinoflagellates were the only group that showed significantly

cells $\mathrm{ml}^{-1}$, and constituting up to $97 \%$ of the total assemblage (Fig. 3). Other diatom genera included Fragilariopsis, Pseudo-nitzschia, Nitzschia, Dactyliosolen and Chaetoceros (Fig. 3), although distinguishing among the various pennate species of the Ross Sea is difficult using only light microscopy. Larger diatoms (Corethron criophilum, Thalassiosira spp., and Rhizosolenia spp.) were present, but never contributed a significant fraction of phytoplankton abundance or biomass, and cells were rarely intact. $P$. antarctica was one of the most abundant species, higher biomass at high phytoplankton biomass stations $\left(\mathrm{r}^{2}=0.52, \mathrm{p}=0.02\right)$.

\section{${ }^{14} \mathrm{C}$-based growth rates}

Growth rates measured in ${ }^{14} \mathrm{C}$ incubations were low throughout the sampling period and ranged from 0.03 to $0.85 \mathrm{~d}^{-1}$, with a mean of $0.14 \mathrm{~d}^{-1}$ (Table $1 \mathrm{~b}$ ), but were similar to growth rates measured in previous studies (Smith et al. 1998, 1999, 2000). Growth rates did not

Table 2. Calculation, based on length, width and shape of cells, of average $( \pm$ SE) cell volume and carbon content of Ross Sea phytoplankton. Volume and carbon content were then used to calculate biomass from cell abundance data. S: sphere; PS: pro late spheroid; R: rectangle; C: cylinder

\begin{tabular}{|lcccccc|}
\hline Species & $\mathrm{N}$ & Length $(\mu \mathrm{m})$ & Width $(\mu \mathrm{m})$ & Shape & Volume $\left(\mu \mathrm{m}^{3}\right)$ & Carbon content $(\mathrm{pg}$ C) \\
\hline Phaeocystis antarctica (solitary) & 50 & $3.4 \pm 0.8$ & - & $\mathrm{S}$ & $21.0 \pm 2.5$ & $1.0 \pm 0.1$ \\
P. antarctica (colonial) & 130 & $4.7 \pm 0.9$ & - & $\mathrm{S}$ & $55.1 \pm 2.3$ & $1.6 \pm 0.0$ \\
Cylindrotheca closterium & 100 & $71.5 \pm 0.9$ & $2.5 \pm 0.0$ & PS & $234 \pm 7.6$ & $28.1 \pm 0.7$ \\
Fragilariopsis spp. & 100 & $28.9 \pm 0.6$ & $4.6 \pm 0.0$ & $\mathrm{R}$ & $621 \pm 42.3$ & $59.0 \pm 3.0$ \\
Dactyliosolen spp. & 100 & $37.9 \pm 0.9$ & $11.5 \pm 0.7$ & $\mathrm{C}$ & $3940 \pm 608$ & $240 \pm 27.7$ \\
Nitzschia longissima & 100 & $1534 \pm 2.6$ & $2.5 \pm 0.0$ & $\mathrm{C}$ & $740 \pm 27.5$ & $67.4 \pm 1.9$ \\
Chaetoceros spp. & 50 & $19.9 \pm 0.9$ & $13.0 \pm 0.4$ & PS & $1770 \pm 206$ & $131 \pm 11.4$ \\
Pseudo-nitzschia spp. & 100 & $92.7 \pm 1.2$ & $5.6 \pm 0.2$ & PS & $1520 \pm 125$ & $116 \pm 7.2$ \\
Dictyocha speculum & 50 & $24.5 \pm 0.2$ & - & S & $7680 \pm 179$ & $614 \pm 14.4$ \\
Dinoflagellate $(>20 \mu \mathrm{m})$ & 100 & $35 \pm 0.4$ & $24.4 \pm 0.3$ & PS & $10900 \pm 826$ & $261 \pm 17.7$ \\
Dinoflagellate $(<20 \mu \mathrm{m})$ & 75 & $19.7 \pm 0.9$ & $12.5 \pm 0.6$ & PS & $1600 \pm 127$ & $1370 \pm 88.9$ \\
\hline
\end{tabular}




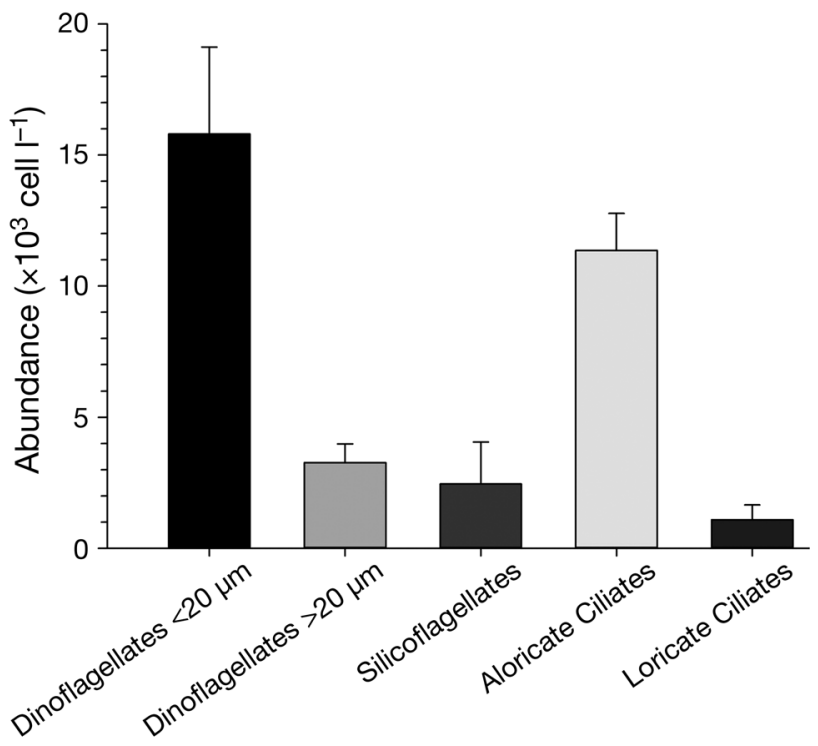

Fig. 4. Mean initial abundance (cells $\mathrm{l}^{-1}$ ) of plankton with demonstrated heterotrophic behavior in dilution experiments $(n=11)$. Error bars are standard errors. Dinoflagellate and silicoflagellate abundance includes all individuals of these functional groups, as individuals were not evaluated as heterotrophs or autotrophs

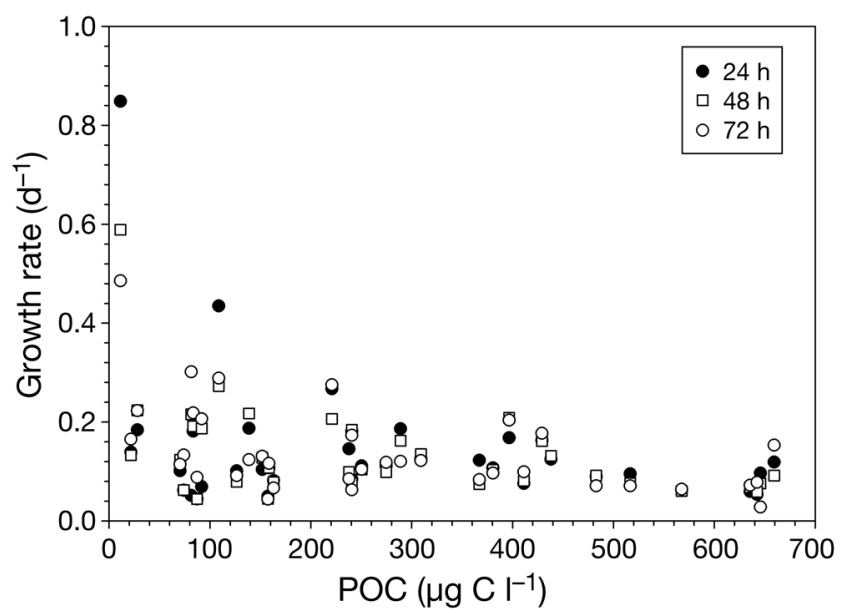

Fig. 5. Phytoplankton growth rates $\left(\mathrm{d}^{-1}\right)$ and particulate organic carbon (POC) concentrations $\left(\mu \mathrm{C}^{-1}\right)$ from ${ }^{14} \mathrm{C}$ incubations in $24 \mathrm{~h}, 48 \mathrm{~h}$ and $72 \mathrm{~h}$ incubations. Growth rates decreased with increasing initial POC concentrations (growth rate $=-0.0002 ; \mathrm{POC}+0.199 ; \mathrm{r}^{2}=0.22 ; \mathrm{p}<0.004$ )

vary with increasing incubation length, strongly suggesting that bottle effects were insignificant in the radioisotope method. They also decreased with increasing initial POC concentrations for all incubation lengths $\left(r^{2}=0.46, p=0.02\right.$; Fig. 5). Growth rates were low in regions with high initial POC concentrations $\left(>480 \mathrm{\mu g} \mathrm{l}^{-1}\right)$, suggesting that growth rates in these regions may be influenced by available resources

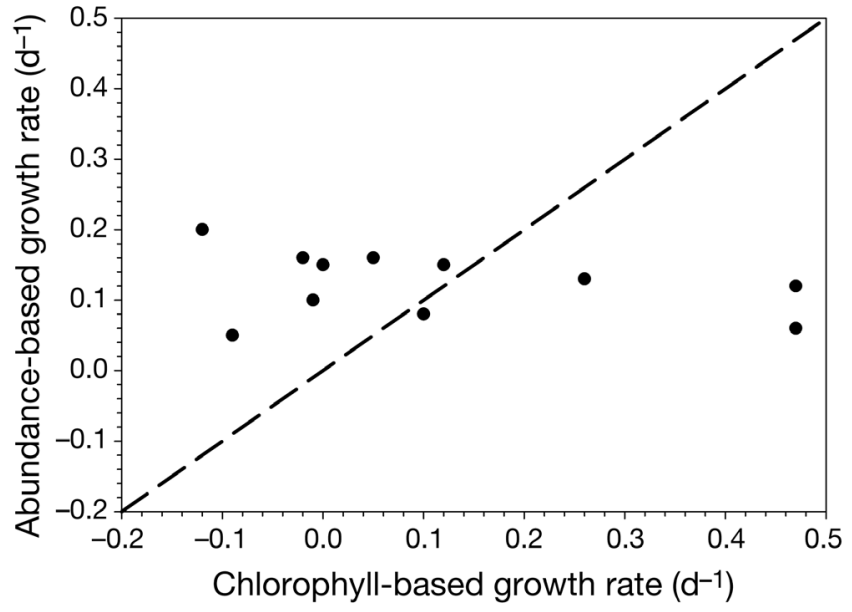

Fig. 6. Relationship between apparent growth rates $\left(\mathrm{d}^{-1}\right)$ of Ross Sea phytoplankton based on chlorophyll and cell abundances in dilution experiments. Dashed line represents a 1:1 change

(e.g. iron) after reaching high phytoplankton biomass, although a variety of factors (such as irradiance and self-shading) may also have driven this relationship (Fig. 5).

\section{Phytoplankton growth rates and mortality in dilution experiments}

Apparent growth rates in dilution experiments were not significantly different from those measured in ${ }^{14} \mathrm{C}$ incubations (Friedman test) and were lower than temperature-defined maximum growth rates ( $t$-test, $\mathrm{p}<0.001)$. Although apparent growth rates based on chlorophyll did not differ significantly from apparent growth rates based on cell abundance (Wilcoxon signed-rank test), there was no correlation between them (Pearson correlation). Apparent growth rates based on chlorophyll ranged from -0.12 to $0.47 \mathrm{~d}^{-1}$, while those based on abundance ranged from 0.05 to $0.20 \mathrm{~d}^{-1}$ (Fig. 6). Elevated growth rates based on chlorophyll were associated with reduced growth rates based on cell abundance, but the trend was not significant (Fig. 6). There were also different relationships between growth rates and environmental conditions depending on the means of biomass assessment.

Apparent growth rates based on chlorophyll increased with increasing temperature $\left(\mathrm{r}^{2}=0.93, \mathrm{p}=\right.$ 0.001; Fig. 7a), and initial carbon:chlorophyll ratios were also correlated with temperature $\left(\mathrm{r}^{2}=0.86, \mathrm{p}<\right.$ 0.001 ; Fig. 7b) and mixed layer depth $(\rho=-0.69, p=$ 0.01). The carbon:chlorophyll ratios shifted in all samples examined microscopically (Fig. 7c). The 

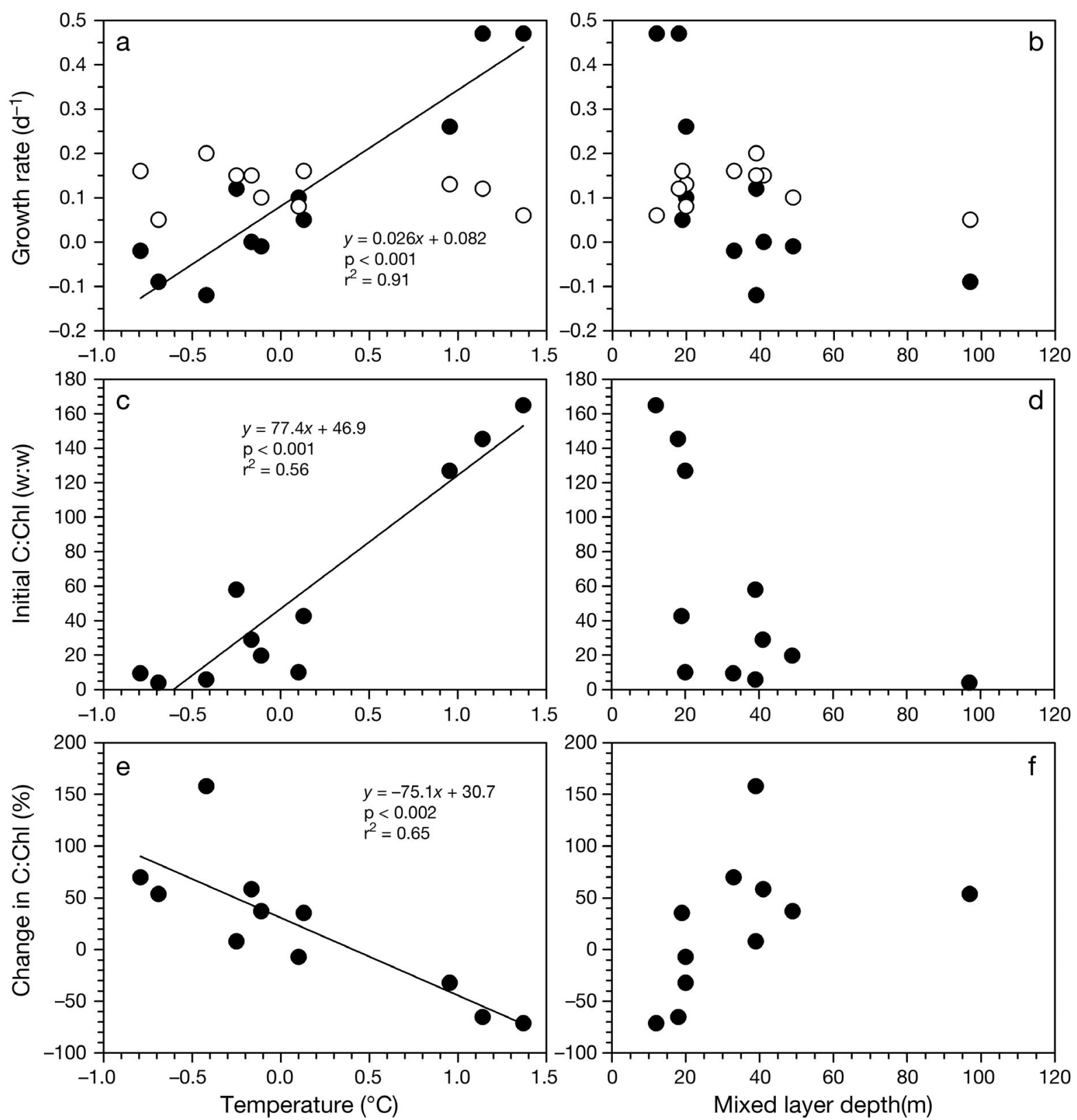

Fig. 7. Relationship between (a) apparent growth rate $\left(\mathrm{d}^{-1}\right)$ of Ross Sea phytoplankton and water temperature was statistically significant for chlorophyll-based growth rates; (b) apparent growth rate and mixed layer depth was statistically significant for chlorophyll-based growth rates (Spearman correlation, $\rho=-0.78 ; \mathrm{p}=0.05$ ), (c) initial carbon:chlorophyll ratios (C:Chl, based on microscopy) and temperature was statistically significant, (d) C:Chl (based on microscopy) and mixed layer depth was statistically significant (Spearman correlation, $\rho=-0.69, \mathrm{p}=0.01)$, (e) change (\%) in C:Chl and temperature was statistically significant, and (f) change (\%) in C:Chl and mixed layer depth was statistically significant (Spearman correlation, $\rho=0.71$, $\mathrm{p}=0.01$ ). Relationships that are statistically significant using Pearson correlations are indicated with a trend line for temperature data. In (a) and (b) apparent growth rates in dilution experiments were determined from changes in chlorophyll ( and cell abundances $(O)$

mean $( \pm \mathrm{SD})$ carbon:chlorophyll ratio in samples taken at the start of experiments was $85 \pm 107$, while values from $72 \mathrm{~h}$ incubations were much lower $(38.2$ \pm 25.6 ). The changes in carbon:chlorophyll ratios from initial to final time points were significantly cor- related to temperature $\left(\mathrm{r}^{2}=0.65, \mathrm{p}=0.002\right.$; Fig. $\left.7 \mathrm{c}\right)$ and mixed layer depth $(\rho=0.71, p=0.01)$.

Phytoplankton mortality rates were only significantly different from zero in 4 of the 11 dilution experiments, and were significantly greater than 
Table 3. Phytoplankton grazing mortality and chlorophyll- and abundance-based growth rates $\left(\mathrm{d}^{-1}\right)$ from dilution experiments in the Ross Sea from 8 to 28 January 2012. The date in the first column indicates when each station, indicated by station number in the second column, was sampled. Initial biomass is based on chlorophyll a concentrations $\left(\mu \mathrm{g} \mathrm{l}^{-1}\right)$ at the time of sampling. The grazing mortality rate is indicated for stations with mortality rates that were significantly different from zero ( $p>0.05 ; \mathrm{NS}=$ not significant). Chlorophyll- and abundance-based calculations of growth rates are shown

\begin{tabular}{|c|c|c|c|c|c|c|c|}
\hline $\begin{array}{l}\text { Date } \\
\text { Jan } \\
2012\end{array}$ & $\begin{array}{l}\text { Stn } \\
\text { no. }\end{array}$ & 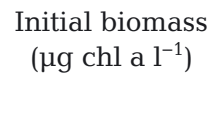 & $\begin{array}{l}\text { Grazing } \\
\text { mortality } \\
\left(\mathrm{d}^{-1}\right)\end{array}$ & $\begin{array}{l}\text { Chlorophyll-based } \\
\text { apparent growth } \\
\text { rate }\left(\mathrm{d}^{-1}\right)\end{array}$ & $\begin{array}{l}\text { Abundance-based } \\
\text { apparent growth } \\
\text { rate }\left(\mathrm{d}^{-1}\right)\end{array}$ & $\begin{array}{l}\text { Chlorophyll-based } \\
\text { intrinsic growth } \\
\text { rate }\left(\mathrm{d}^{-1}\right)\end{array}$ & $\begin{array}{l}\text { Abundance-based } \\
\text { intrinsic growth } \\
\text { rate }\left(\mathrm{d}^{-1}\right)\end{array}$ \\
\hline 08 & 3 & 1.08 & 0.18 & -0.02 & 0.16 & 0.16 & 0.34 \\
\hline 09 & 4 & 9.45 & NS & 0.00 & 0.15 & 0.00 & 0.15 \\
\hline 14 & 9 & 1.65 & 0.30 & 0.26 & 0.13 & 0.56 & 0.43 \\
\hline 17 & 19 & 1.71 & NS & 0.47 & 0.12 & 0.47 & 0.12 \\
\hline 17 & 22 & 0.93 & -0.20 & 0.47 & 0.06 & 0.27 & -0.14 \\
\hline 21 & 37 & 4.66 & NS & 0.05 & 0.16 & 0.05 & 0.16 \\
\hline 22 & 52 & 2.96 & NS & 0.12 & 0.15 & 0.12 & 0.15 \\
\hline 25 & 60 & 5.95 & NS & -0.09 & 0.05 & -0.09 & 0.05 \\
\hline 25 & 61 & 7.14 & NS & -0.12 & 0.20 & -0.12 & 0.20 \\
\hline 28 & 79 & 0.22 & NS & 0.10 & 0.08 & 0.10 & 0.08 \\
\hline 28 & 80 & 0.33 & 0.09 & -0.01 & 0.10 & 0.08 & 0.19 \\
\hline
\end{tabular}
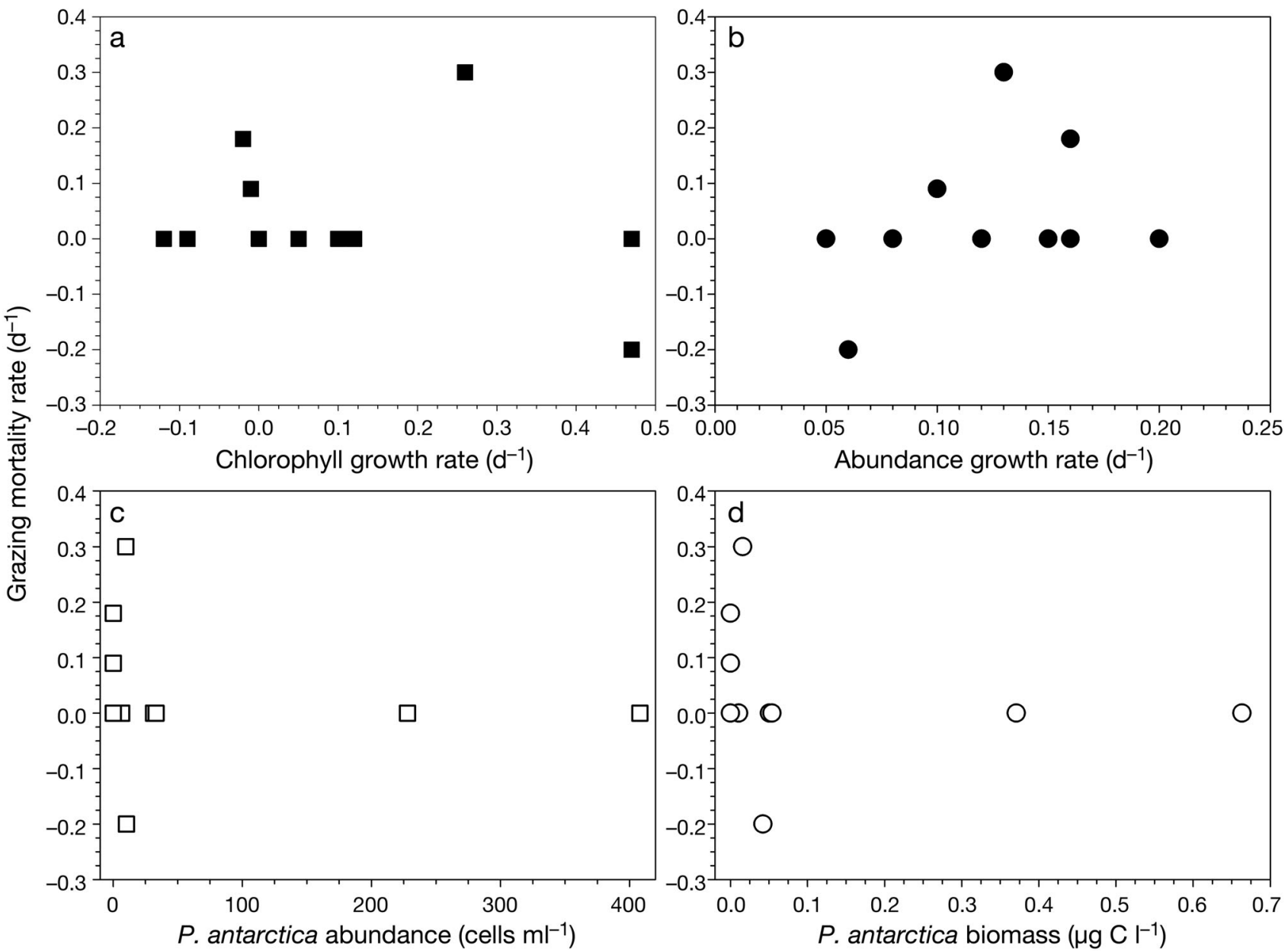

Fig. 8. Phytoplankton grazing mortality rates $\left(\mathrm{d}^{-1}\right)$ in dilution experiments as a function of apparent growth rates $\left(\mathrm{d}^{-1}\right)$ based on (a) chlorophyll and (b) cell abundances, and of varying initial (c) abundance (cells $\mathrm{ml}^{-1}$ ) and (d) biomass ( $\mu \mathrm{g} \mathrm{C} \mathrm{l}^{-1}$ ) of colonial Phaeocystis antarctica. All non-significant phytoplankton grazing mortality rates are set to zero 
zero in only 3 of those (Table 3). A mortality rate significantly less than zero $\left(-0.20 \mathrm{~d}^{-1}\right)$ occurred at the second occupation of the low biomass station (Stn 22), and the highest mortality rate $\left(0.30 \mathrm{~d}^{-1}\right)$ occurred at the initial occupation of this station (Stn 9) $3 \mathrm{~d}$ earlier (Table 3). Significant mortality rates were also measured at Stn $3\left(m=0.18 \mathrm{~d}^{-1}\right)$ and Stn $80\left(m=0.09 \mathrm{~d}^{-1}\right)$ (Table 3$)$. The 3 experiments that yielded significant, positive mortality rates occurred at stations with relatively low initial biomass ( 0.33 to $1.08 \mu \mathrm{g} \mathrm{chl} \mathrm{a}^{-1}$ ), but there was no significant correlation between initial chlorophyll and mortality (Pearson correlation, $\mathrm{p}=0.65$ ). At the stations with significant mortality rates, apparent growth rates based on chlorophyll and cell abundance ranged from -0.02 to $0.26 \mathrm{~d}^{-1}$ and 0.10 to $0.16 \mathrm{~d}^{-1}$, respectively, but there was no correlation between either measure of growth rates and mortality rates (Pearson correlation, $\mathrm{p}=0.30$ and $\mathrm{p}=0.72$, respectively; Fig. 8). There was also no relationship between $P$. antarctica and phytoplankton mortality rates; mortality rates did not differ significantly with abundance or biomass of colonial P. antarctica (Fig. 8). Colonial $P$. antarctica was present at stations that yielded significant mortality rates but was also absent from several stations that did not yield significant mortality rates (Fig. 8). Biomass and relative abundance of all groups (diatoms, small and large dinoflagellates, $P$. antarctica, silicoflagellates, and loricate and aloricate ciliates) did not significantly change during incubations (Student's $t$-test, $\mathrm{p}>0.05)$.

\section{DISCUSSION}

Our objectives of this study were 3-fold: to examine the effect of incubation length on measured growth rates in ${ }^{14} \mathrm{C}$ incubations and dilution experiments; to compare phytoplankton growth rates measured using ${ }^{14} \mathrm{C}$ incubations to those measured within dilution experiments; and to assess the absolute rates of phytoplankton growth in the Ross Sea and their relationship to rates predicted by Eppley (1972). Growth rate measurements are subject to errors resulting from incubation and experimental techniques, which often are inadequately considered in their analyses. Based on the methodological designs used to estimate growth rates, some procedures may be more appropriate than others, but regardless of the methods, it is important that any inherent uncertainties are acknowledged and, when possible, quantified. The growth rate estimates from the dilution method and ${ }^{14} \mathrm{C}$ incubations both rely on key assumptions concerning grazing in the incubations. For the dilution method to provide a reliable estimate of growth and grazing rates, it must be assumed that neither allelopathy or mixotrophy are major factors operating in incubations; similarly, for the ${ }^{14} \mathrm{C}$ incubations to accurately assess growth rates, grazing should be quantitatively unimportant. While ${ }^{14} \mathrm{C}$ incubations and growth rates based on cell abundance measure changes in carbon, growth rates estimated from dilution experiments typically rely on changes in chlorophyll, which requires that the system exhibits balanced growth (i.e. carbon and chlorophyll increase in proportion to each other).

\section{Photoacclimation in dilution experiments}

In our dilution experiments growth rates based on changes in chlorophyll were negative at stations that were characterized by low temperatures and deep mixed layers. Growth rates based on cell abundance, taken from the same samples, were always positive and relatively constant. There are errors associated with measuring growth rates from cell abundance data. Possible sources of error in our study were that picophytoplankton were not counted, cell volume was calculated from approximate geometric shapes (potentially under- or overestimating the average cell volume), cell volume shrank after preservation (Montagnes et al. 1994), and errors were introduced in estimating cellular carbon from volume. Additionally, the carbon contributed by colonial Phaeocystis antarctica was underestimated, as mucus-related carbon, which can account for up to $33 \%$ of the total carbon content of P. antarctica colonies (Mathot et al. 2000), was not included. However, the discrepancy between chlorophyllbased and abundance-based growth rates was likely due to unbalanced growth in dilution experiments as a result of photoacclimation, in which phytoplankton under increased irradiance increased growth while the chlorophyll pools remained relatively unchanged (resulting in increased carbon chlorophyll ratios). Generally, phytoplankton under decreased irradiance exhibit increased chlorophyll levels (resulting in decreased carbon:chlorophyll ratios) (Prézelin \& Matlick 1980, Ross et al. 2011). This would have resulted in a disproportionate increase or decrease in chlorophyll concentrations relative to total phytoplankton carbon, similar to the unbalanced growth seen in the dilution experiments conducted by Caron et al. (2000). 
Based on the relationship between the initial carbon:chlorophyll ratio and shifts in carbon:chlorophyll ratios during dilution experiments (Fig. 7), it appears that altered chlorophyll per cell concentrations due to variable irradiance had a substantial effect on measured growth rates. Negative chlorophyll-based growth rates occurred at stations characterized by low initial carbon:chlorophyll ratios, suggesting that samples from these stations were adapted to relatively low photon flux densities. These stations were characterized by relatively deep mixed layers, and although chlorophyll-based growth rates were negative, abundance-based growth rates remained positive, indicating that a decrease in chlorophyll per cell occurred. In contrast, experiments at stations with shallow mixed layers had high initial carbon:chlorophyll ratios, typical of a phytoplankton assemblage acclimated to high irradiances. In response to conditions in the incubator, carbon:chlorophyll ratios decreased over the incubation indicating an increase in chlorophyll per cell, which would be expected in response to decreased irradiance (Prézelin \& Matlick 1980). Even though samples were taken from the same depths and incubated under $36 \%$ of surface irradiance, the relationship between mixed layer depth and carbon:chlorophyll ratios indicates that phytoplankton were adapted to different irradiance conditions across the sampling region, leading to unbalanced growth among incubations, as irradiance experienced by phytoplankton in the water column is difficult to replicate in shipboard incubations (McManus 1995). Our experiments were conducted as extended incubations, but photoacclimation can occur rapidly (within $12 \mathrm{~h}$ in cultured samples; Prézelin \& Matlick 1980). In a heterogeneous region such as the Ross Sea, where irradiance varies temporally, spatially and with depth, studies assessing growth rates using chlorophyll concentrations need to carefully monitor shifts in chlorophyll per cell in response to changing irradiance, since photoacclimation could lead to inaccurate growth rates estimates.

\section{Phytoplankton mortality rates in dilution experiments}

Dilution experiments yielded phytoplankton mortality rates that were extremely low, but similar to those seen previously in the Ross Sea (Caron et al. 2000), suggesting that grazing losses by microzooplankton are small and are not a large source of error in ${ }^{14} \mathrm{C}$ incubations. The majority of the experiments yielded phytoplankton grazing mortality rates that were not significantly different from zero; furthermore, the rates that were significantly greater than zero were low relative to rates measured in the Sargasso Sea (e.g. Lessard \& Murrell 1998), but not unusual for polar regions (Garzio \& Steinberg 2013). The low rates could not be directly attributed to low abundance of microzooplankton (Fig. 3), as ciliate abundance was similar to abundances reported previously in the Southern Ocean (Caron et al. 2000). Additionally, previous studies from this region were unable to link low phytoplankton mortality to microheterotroph abundance (Caron et al. 2000). Previous studies were also unable to attribute low grazing mortality to high phytoplankton abundance and subsequent reductions in clearance rates of microzooplankton (Landry 1993). If a threshold effect occurred in these dilution experiments, it could have led to underestimates of phytoplankton mortality rates at stations with high initial biomass (Calbet et al. 2011); however, there was no direct relationship between initial biomass and grazing mortality, and several stations with low initial biomass also did not yield significant grazing mortality rates. The lack of any clear relationship between initial biomass and phytoplankton grazing mortality rates and results of previous dilution experiments conducted under similar conditions (Caron et al. 2000) indicate that it is unlikely that low grazing mortality rates are due to high prey concentrations.

Alternative explanations for these extremely low phytoplankton mortality rates measured in the Ross Sea include depression of microzooplankton herbivory at low temperatures and error in measurements of phytoplankton grazing rates due to the presence of $P$. antarctica. Previous dilution experiments in the Southern Ocean have found a positive relationship between temperature and phytoplankton grazing mortality rates as low temperatures yielded low grazing mortality rates (Schmoker et al. 2013), and dilution experiments conducted at temperatures we observed have yielded significantly lower phytoplankton mortality rates than those at higher temperatures (Caron et al. 2000). Rose \& Caron (2007) found that growth rates of herbivorous protists declined faster than those of phototrophic protists when assessed relative to temperature, suggesting that the low phytoplankton mortality rates could result from low temperatures. However, Sherr \& Sherr (2009, p. 255) argue that protist growth was largely regulated by prey abundance and low protist biomass, and suggested that temperature is not 'a universally important factor in controlling the biomass of phytoplankton when nutrients are not limit- 
ing to phytoplankton growth'. Several studies conducted in regions with high abundances of Phaeocystis have found low phytoplankton mortality and growth rates and attributed these low rates to the presence of Phaeocystis (Caron et al. 2000, Calbet et al. 2011). The results from our study do not support the hypothesis that low grazing mortality rates may be attributed solely to the presence of $P$. antarctica. If low phytoplankton mortality rates were caused by errors due to the deterrence of grazing by colonial $P$. antarctica, grazing mortality rates should be highest in those experiments with the lowest abundance of colonial $P$. antarctica or at stations where this form was absent; however, this was not found to be the case. It is more likely that these low grazing rates we observed are due to low temperatures.

\section{Loss of fixed ${ }^{14} \mathrm{C}$ in extended incubations}

${ }^{14} \mathrm{C}$ incubations in the Ross Sea are typically conducted over $24 \mathrm{~h}$ to accurately measure phytoplankton carbon incorporation over the entire diel cycle. However, extending the incubation lengths to $72 \mathrm{~h}$ did not affect measured growth rates, indicating that the loss of fixed ${ }^{14} \mathrm{C}$ due to respiration was minimal. In comparing productivity using ${ }^{14} \mathrm{C}$ and $\mathrm{O}_{2}$ methods, Ryther \& Vaccaro (1954) found that although productivity measured by the 2 methods agreed in $24 \mathrm{~h}$ incubations, results from the 2 methods diverged in extended incubations; subsequent studies attributed this difference to respiration of fixed carbon (Laws et al. 2000). If respiration by phytoplankton represented a major loss of fixed carbon, measured growth rates should have decreased as incubation length increased, as respiration initially uses non-labeled carbon (Moigis 2000). No significant difference in measured growth rates was observed with extended incubations, indicating that respiration did not significantly bias growth rate estimates. This is not unexpected, as low temperatures are expected to yield low respiration rates (Robinson \& Williams 1993, del Giorgio \& Duarte 2002). An additional source of error in extended ${ }^{14} \mathrm{C}$ incubations might be the ${ }^{14} \mathrm{C}$ carbon released by grazing (Menden-Deuer 2012). Because grazing rates in the Ross Sea are low and growth rate estimates in ${ }^{14} \mathrm{C}$ incubations did not vary with incubation length, we suggest that grazing did not significantly affect isotopic growth rates. Finally, changes in assemblage composition could occur, but were not observed in our samples. Extending incubation length in warmer waters may induce additional uncertainties that we did not encounter.

\section{Absolute phytoplankton growth rates relative to predicted rates}

The average growth rate for all stations as measured by $24 \mathrm{~h}^{14} \mathrm{C}$ incubations was $0.11 \pm 0.14 \mathrm{~d}^{-1}$, and ranged from 0.03 to $0.85 \mathrm{~d}^{-1}$ (Table $1 \mathrm{~b}$ ). The substantial spatial variability suggests that growth rates are controlled by the various processes that regulate photosynthesis (e.g. micronutrient concentrations and irradiance availability). The mean rate is substantially lower than that predicted by Eppley's (1972) synthesis of data from cultures, which is not surprising given that the estimated rates from the field likely reflect the entire range of environmental controls and limitations. Our maximum growth rates equal or exceed those predicted by Eppley's equation, but because we cannot know with certainty which rates were approaching maximum growth rates, we cannot say with confidence that Eppley's estimate for polar waters is an underestimate. More detailed measurements of maximum growth rates under optimal nutrient and irradiance conditions are required to constrain the temperature limitations of growth rates in polar waters.

\section{CONCLUSIONS}

Our results suggest that in the Ross Sea ${ }^{14} \mathrm{C}$ incubations are more appropriate for measuring phytoplankton growth rates than dilution experiments. Growth rates measured in ${ }^{14} \mathrm{C}$ incubations were relatively constant through $72 \mathrm{~h}$, suggesting that measurements of growth rate were not significantly affected by the loss of fixed ${ }^{14} \mathrm{C}$ through grazing and respiration, and therefore the ${ }^{14} \mathrm{C}$ incubation method provides an accurate estimate of phytoplankton growth in the Ross Sea. Additionally, low phytoplankton grazing rates in dilution experiments, likely due to low temperatures rather than solely the result of the presence of Phaeocystis antarctica (or other factors such as low microzooplankton biomass), further suggest that grazing is unlikely to significantly affect measured growth rates in ${ }^{14} \mathrm{C}$ incubations and indicate that the microbial food web does not play a large role in controlling phytoplankton growth in the region (Caron et al. 2000). However, discrepancies between chlorophyll- and abundance-based growth rates in dilution experiments indicate that chlorophyll-based growth rates may be inaccurate due to unbalanced growth in incubations resulting from photoacclimation (Schmoker et al. 2013). We suggest that multi-day incubations are appropriate in polar 
regions where mortality rates are near zero in dilution experiments, as long as changes in stoichiometry and abundance are monitored. In polar regions where environmental conditions vary spatially, ${ }^{14} \mathrm{C}$ incubations provide a suitable means for measuring the low phytoplankton growth rates required for biogeochemical models.

Acknowledgements. This research was supported by National Science Foundation grant ANT-0944254 to WOS. P. Sedwick generously allowed the use of his iron data. We thank all our PRISM colleagues for their assistance at sea, especially L. Delizo, H. Doan, S. Charles, E. Olson, and T. Ryan-Keogh for assisting in sample processing. This is VIMS contribution number 3444 .

\section{LITERATURE CITED}

Agis M, Granda A, Dolan JR (2007) A cautionary note: examples of possible microbial community dynamics in dilution grazing experiments. J Exp Mar Biol Ecol 341: 176-183

Arrigo KR, van Dijken G, Long M (2008a) Coastal Southern Ocean: a strong anthropogenic $\mathrm{CO}_{2}$ sink. Geophys Res Lett 35:L21602. doi:10.1029/2008GL035624

Arrigo KR, van Djiken G, Bushinsky S (2008b) Primary production in the Southern Ocean, 1997-2006. J Geophys Res 113, CO8004, doi:10.1029/2007JC004551

Beers JR, Stewart GL (1970) Numerical abundance and estimated biomass of microzoo plankton. Bull Scripps Inst Oceanogr Univ Calif 17:67-87

- Bissinger JE, Montagnes DJS, Sharples J, Atkinson D (2008) Predicting marine phytoplankton maximum growth rates from temperature: improving on the Eppley curve using quantile regression. Limnol Oceanogr 53:487-493

Calbet A, Saiz E, Almeda R, Movilla JI, Alcaraz M (2011) Low microzooplankton grazing rates in the Arctic Ocean during a Phaeocystis pouchetii bloom (Summer 2007): fact or artifact of the dilution technique? J Plankton Res 33:687-701

Caron DA, Dennett MR, Lonsdale DJ, Moran DM, Shalpyonok L (2000) Microzooplankton herbivory in the Ross Sea, Antarctica. Deep-Sea Res II 47:3249-3272

> Davidson AT, Marchant HJ (1987) Binding of manganese by Antarctic Phaeocystis pouchetii and the role of bacteria in its release. Mar Biol 95:481-487

del Giorgio PA, Duarte CM (2002) Respiration in the open ocean. Nature 420:379-384

> DiTullio GR, Laws EA (1983) Estimates of phytoplankton N uptake based on ${ }^{14} \mathrm{CO}_{2}$ incorporation into protein. Limnol Oceanogr 28:177-185

Ducklow HW, Hill S (1985) The growth of heterotrophic bacteria in the surface waters of warm core rings. Limnol Oceanogr 30:241-262

El-Sayed SZ, Biggs DC, Holm-Hansen O (1983) Phytoplankton standing crop, primary productivity, and near-surface nitrogenous nutrient fields in the Ross Sea, Antarctica. Deep-Sea Res 30:871-886

Eppley RW (1968) An incubation method for estimating the carbon content of phytoplankton in natural samples. Limnol Oceanogr 13:574-582
Eppley RW (1972) Temperature and phytoplankton growth in the sea. Fish Bull 70:1063-1085

Eppley RW (1980) Estimating phytoplankton growth rates in the central oligotrophic oceans. In: Falkowski PG (ed) Primary productivity in the sea. Plenum Publishing, New York, NY, p 231-242

Eppley RW, Reid FMH, Strickland JDH (1970) Estimates of phytoplankton crop size, growth rate, and primary production. Bull Scripps Inst Oceanogr Univ Calif 17:33-42

> Flynn KJ, Stoecker DK, Mitra A, Raven JA and others (2013) Misuse of the phytoplankton-zooplankton dichotomy: the need to assign organisms as mixotrophs within plankton functional types. J Plankton Res 35:3-11

> Gallegos CL, Vant WN (1996) An incubation procedure for estimating carbon-to-chlorophyll ratios and growthirradiance relationships of estuarine phytoplankton. Mar Ecol Prog Ser 138:275-291

> Gardner WD, Richardson MJ, Smith WO (2000) Seasonal patterns of water column particulate organic carbon and fluxes in the Ross Sea, Antarctica. Deep-Sea Res II 47: 3423-3449

> Garzio LM, Steinberg DK (2013) Microzooplankton community composition along the Western Antarctic Peninsula. Deep-Sea Res I 77:36-49

Hötzel G, Croome R (1999) A phytoplankton methods manual for Australian freshwaters. LWRRDC Occasional Paper 22/99, Land and Water Resources Research and Development Corporation, Canberra

JGOFS (Joint Global Ocean Flux Study) (1996). Protocols for the Joint Global Ocean Flux Study (JGOFS) core measurements. JGOFS Report No. 19. Scientific Committee on Oceanic Research, International Council of Scientific Unions, Intergovernmental Oceanographic Commission, Bergen

Landry MR (1993) Estimating rates of growth and grazing mortality of photoautotrophic plankton by dilution. In: Kemp PF, Sherr BF, Sherr EB, Cole JJ (eds) Handbook of methods in aquatic microbial ecology. Lewis Publishers, Boca Raton, FL, p 715-722

> Landry MR (2014) On database biases and hypothesis testing with dilution experiments: response to comment by Latasa. Limnol Oceanogr 59:1095-1096

> Landry MR, Hassett RP (1982) Estimating the grazing impact of marine microzooplankton. Mar Biol 67: 283-288

> Landry MR, Selph KE, Brown SL, Abbott MR and others (2002) Seasonal dynamics of phytoplankton in the Antarctic Polar Front region at $170^{\circ} \mathrm{W}$. Deep-Sea Res II 49:1843-1865

> Landry MR, Brown SL, Rii YM, Selph KE, Bidigare RR, Yang EJ, Simmons MP (2008) Depth stratified phytoplankton dynamics in Cyclone Opal, a subtropical mesoscale eddy. Deep-Sea Res II 55:1348-1359

Laws EA (2013) Evaluation of in situ phytoplankton growth rates: a synthesis of data from varied approaches. Annu Rev Mar Sci 5:247-268

Laws EA, DiTullio GR, Redalje DG (1987) High phytoplankton growth and production rates in the North Pacific subtropical gyre. Limnol Oceanogr 32:905-918

> Laws EA, Landry MR, Barber RT, Campbell L, Dickson M, Marra J (2000) Carbon cycling in primary production bottle incubations: inferences from grazing experiments and photosynthetic studies using ${ }^{14} \mathrm{C}$ and ${ }^{18} \mathrm{O}$ in the Arabian Sea. Deep-Sea Res II 47:1339-1352

> Lessard EJ, Murrell MC (1998) Microzooplankton herbivory 
and phytoplankton growth in the northwestern Sargasso Sea. Aquat Microb Ecol 16:173-188

Li QP, Franks PJS, Landry MR (2011) Microzooplankton grazing dynamics: parameterizing grazing models with dilution experiment data from the California Current Ecosystem. Mar Ecol Prog Ser 438:59-69

Mathot S, Smith WO, Carlson CA, Garrison DL, Gowing MM, Vickers CL (2000) Carbon partitioning within Phaeocystis antarctica (Prymnesiophyceae) colonies in the Ross Sea, Antarctica. J Phycol 36:1049-1056

McManus GB (1995) Phytoplankton abundance and pigment changes during simulated in situ dilution experiments in estuarine waters: possible artifacts caused by algal light adaptation. J Plankton Res 17:1705-1716

> Menden-Deuer S (2012) Structure-dependent phytoplankton photosynthesis and production rates: implications for the formation, maintenance, and decline of plankton patches. Mar Ecol Prog Ser 468:15-30

Menden-Deuer S, Fredrickson K (2010) Structure-dependent, protistan grazing and its implication for the formation, maintenance and decline of plankton patches. Mar Ecol Prog Ser 420:57-71

> Menden-Deuer S, Lessard EJ (2000) Carbon to volume relationships for dinoflagellates, diatoms, and other protist plankton. Limnol Oceanogr 45:569-579

Moigis AG (2000) Photosynthetic rates in the surface waters of the Red Sea: the radiocarbon versus the non-isotopic dilution method. J Plankton Res 22:713-727

Montagnes DJS, Berges JA, Harrison PJ, Taylor FJR (1994) Estimating carbon, nitrogen, protein, and chlorophyll a from volume in marine phytoplankton. Limnol Oceanogr 39:1044-1060

Mosby AF (2013) Phytoplankton growth rates in the Ross Sea, Antarctica. MSc Thesis, Virginia Institute of Marine Science, Gloucester Point, VA

Neter J, Kutner MH, Nachtsheim CJ, Wasserman W (1996) Applied linear statistical models. Irwin, Chicago, IL

> Prézelin BB, Matlick HA (1980) Time-course of photoadaptation in the photosynthesis-irradiance relationship of a dinoflagellate exhibiting photosynthesis periodicity. Mar Biol 58:85-96

Robinson C, Williams PJ (1993) Temperature and Antarctic plankton community respiration. J Plankton Res 15: 1035-1051

Rose JM, Caron DA (2007) Does low temperature constrain the growth rates of heterotrophic protists? Evidence and implications for algal blooms in cold waters. Limnol Oceanogr 52:886-895

Ross ON, Geider RJ, Berdalet E, Artigas ML, Piera J (2011) Modelling the effect of vertical mixing on bottle incubations for determining in situ phytoplankton dynamics. I. Growth rates. Mar Ecol Prog Ser 435:13-31

Ryther JH, Vaccaro RF (1954) A comparison of $\mathrm{O}_{2}$ and ${ }^{14} \mathrm{C}$ methods of measuring marine photosynthesis. ICES J Mar Sci 20:25-37

Sarmiento JL, Hughes TMC, Stouffer RJ, Manabe S (1998) Simulated response of the ocean carbon cycle to anthropogenic climate warming. Nature 393:245-249

Schmoker C, Hernandez-Leon S, Calbet A (2013) Microzooplankton grazing in the oceans: impacts, data variability, knowledge gaps and future directions. J Plankton Res 35:691-706

Editorial responsibility: Hugh Ducklow, Woods Hole, Massachusetts, USA
Sedwick PN, DiTullio GR, Mackey DJ (2000) Iron and manganese in the Ross Sea, Antarctica: seasonal iron limitation in Antarctic shelf waters. J Geophys Res 105: 11321-11326

Sedwick PN, Marsay CM, Sohst BM, Aguilar-Islas AM and others (2011) Early season depletion of dissolved iron in the Ross Sea polynya: implications for iron dynamics on the Antarctic continental shelf. J Geophys Res 116, C12019, doi:10.1029/2010JC006553

> Sheldon RW, Sutcliffe WH (1978) Generation times of 3 hours for Sargasso Sea microplankton determined by ATP analysis. Limnol Oceanogr 23:1051-1055

> Sherr EB, Sherr BF (2009) Capacity of herbivorous protists to control initiation and development of mass phytoplankton blooms. Aquat Microb Ecol 57:253-262

Smayda TJ (1978) From phytoplankton to biomass. In: Sournia A (ed) Phytoplankton manual. Monographs on Oceanographic Methodology 6, UNESCO, Paris, p 273-279

Smith WO, Comiso JC (2008) Influence of sea ice on primary production in the Southern Ocean: a satellite perspective. J Geophys Res 113, C05S93, doi:10.1029/2007JC 004251

Smith WO, Gordon LI (1997) Hyperproductivity of the Ross Sea (Antarctica) polynya during austral spring. Geophys Res Lett 24:233-236

Smith WO, Carlson CA, Ducklow HW, Hansell DA (1998) Growth dynamics of Phaeocystis antarctica-dominated plankton assemblages from the Ross Sea. Mar Ecol Prog Ser 168:229-244

Smith WO, Nelson DM, Mathot S (1999) Phytoplankton growth rates in the Ross Sea, Antarctica, determined by independent methods: temporal variations. J Plankton Res 21:1519-1536

Smith WO, Marra J, Hiscock MR, Barber RT (2000) The seasonal cycle of phytoplankton biomass and primary productivity in the Ross Sea, Antarctica. Deep-Sea Res II 47 : 3119-3140

Smith WO, Dennett MR, Mathot S, Caron DA (2003) The temporal dynamics of the flagellated and colonial stages of Phaeocystis antarctica in the Ross Sea. Deep-Sea Res II 50:605-617

Smith WO, Tozzi S, Long MC, Sedwick PN and others (2013) Spatial and temporal variations in variable fluorescence in the Ross Sea (Antarctica): oceanographic correlates and bloom dynamics. Deep-Sea Res I 79: 141-155

Smith WO, Ainley DG, Arrigo KR, Dinniman MS (2014) The Oceanography and ecology of the Ross Sea. Annu Rev Mar Sci 6:469-487

> Strom SL, Olson MB, Macri EL, Mordy CW (2006) Crossshelf gradients in phytoplankton community structure, nutrient utilization, and growth rate in the coastal Gulf of Alaska. Mar Ecol Prog Ser 328:75-92

Tagliabue A, Arrigo KR (2003) Anomalously low zooplankton abundance in the Ross Sea: an alternative explanation. Limnol Oceanogr 48:686-699

Thomson RE, Fine IV (2003) Estimating mixed layer depth from oceanic profile data. J Atmos Ocean Technol 20: 319-329

> Venrick EL, Beers JR, Heinbokel JF (1977) Possible consequences of containing microplankton for physiological rate measurements. J Exp Mar Biol Ecol 26:55-76

Submitted: April 14, 2014; Accepted: November 17, 2014

Proofs received from author(s): February 13, 2015 